(Uniwersytet Warszawski, e-mail: marta.piasecka@uw.edu.pl)

ORCID: 0000-0001-6444-5867

\title{
PARTYKUEY W NAUCZANIU JĘZYKA POLSKIEGO JAKO OBCEGO NA POZIOMIE A1. NA MATERIALE PODRĘCZNIKÓW I SŁOWNIKÓW PRZEZNACZONYCH DLA UCZĄCYCH SIĘ JĘZYKA POLSKIEGO JAKO OBCEGO
}

Wyrazy i wyrażenia, które sa zaliczane do klasy partykuł, można odnaleźć w dialogach, tekstach i zdaniach w ćwiczeniach zamieszczonych w podręcznikach, zbiorach ćwiczeń i innych materiałach do nauczania języka polskiego jako obcego już na poziomie A1. Znajdują się one również na listach minimum i listach podstawowych słownictwa, tworzonych na potrzeby nauczania języka polskiego cudzoziemców. Pewien zasób partykuł jest również odnotowany w słownikach przeznaczonych dla cudzoziemców uczących się polszczyzny, jednak - jak wynika z przeglądu leksykonów - nie jest on pełny.

Partykuły sa używane w tekstach (zdaniach) w podręcznikach, lecz ani ich znaczenie, ani użycie nie sa przez autorów materiałów dydaktycznych wyjaśniane. Nie ma także ćwiczeń, dzięki którym uczący się mogliby nabyć umiejętność posługiwania się nimi we własnych wypowiedziach, ćwiczeń zdających sprawę $z$ ich dorematyczności, a zatem zmiennej pozycji w zdaniu, czy też ćwiczeń wyczulających na niewielkie czasami różnice znaczenia. Znaczenie partykuł jest dla nauczycieli niekiedy trudne do wyjaśnienia, ekwiwalenty obcojęzyczne często nie sa równoznaczne, a słowniki niestety nie są pomocne, gdyż definicje w nich zawarte sa często zbyt ogólne i posługują się słownictwem wykraczającym poza możliwości uczących się na poziomie początkującym, a także średniozaawansowanym. Aby znaleźć odpowiedni sposób wprowadzania i uczenia użycia partykuł na wszystkich etapach nauczania języka polskiego jako obcego, należy zestawić listę partykuł występujących w podręcznikach i innych materiałach dydaktycznych, zaproponować ich definicje oraz określić zakresy stosowania.

Celem tego artykułu jest ustalenie, które partykuły zostały użyte $\mathrm{w}$ podręcznikach na poziomie A1, a więc $z$ którymi jednostkami stykaja się uczacy się języka polskiego jako obcego na samym początku nauki. Następnie - skonfrontowanie ich $z$ listami słownictwa przeznaczonego do przyswojenia na etapie poczatkowym oraz porównanie ich użyć $z$ informacjami podanymi przez słowniki. 
Partykuły i zdania, w których zostały użyte, zostały wyekscerpowane $z$ trzech popularnych podręczników do nauczania języka polskiego jako obcego na poziomie A1: Polski krok po kroku. Seria podręczników do nauki języka polskiego dla obcokrajowców. Poziom A1, Iwona Stempek $\mathrm{i}$ in., Kraków 2010; Polski jest cool. Seria do nauki języka polskiego jako obcego na poziomie A1. Ksiażka studenta, Ewa Piotrowska-Rola, Marzena Porębska, Lublin 2013; Hurra!!! Po polsku 1. Podręcznik studenta, Małgorzata Małolepsza, Aneta Szymkiewicz, wyd. II, Kraków 2006 [wyd. I - 2003]. Każdy z tych podręczników różni się od pozostałych zasobem słownictwa i stopniem trudności, a w związu $z$ tym jest skierowany do adresatów różniących się nieco poziomem zaawansowania. Podręcznik wymieniony jako ostatni, najstarszy, najbardziej odbiega od poziomu A1, prezentuje nieco wyższy poziom językowy niż podręczniki publikowane później, po ukazaniu się wytycznych Europejskiego systemu opisu ksztatcenia językowego [2003].

Definicja klasy partykuł została przyjęta za Słownikiem gniazdowym partykut polskich (SGPP) [Grochowski, Kisiel, Żabowska 2014], zgodnie $z$ która partykuła to operator metatekstowy, otwierajacy jedna pozycje dla rematu wypowiedzenia, nienacechowana gramatycznie ani semantycznie; współwystępujący $z$ wyrażeniami wypełniającymi tę pozycję, ale niewchodzący $z$ nimi w zależność syntaktyczna; niewchodzący samodzielnie na pozycje otwierane przez jednostki innych klas gramatycznych; komentujacy remat wypowiedzenia (dorematyczny) [Grochowski, Kisiel, Żabowska 2014, 26]. Z podręczników wyekscerpowano 20 partykuł w rozumieniu SGPP: być może, chyba, głównie, jednak, jeszcze, może, na pewno, na przykład, nawet, oczywiście, po prostu, przecież, raczej, również, szczególnie, także, też, tylko, w końcu, właśnie. Jedenaście $z$ nich wystapiło wielokrotnie $\mathrm{i} \mathrm{w}$ większości (poza na przykład, również, szczególnie, także) we wszystkich trzech wybranych podręcznikach: chyba, jeszcze, może, na pewno, na przykład, oczywiście, również, szczególnie, także, té், tylko, a dziewięć ma tylko nieliczne poświadczenia, $z$ czego prawie wszystkie (poza głównie i nawet) zaledwie $\mathrm{w}$ jednej z wybranych publikacji: być może, głównie, jednak, nawet, po prostu, przecież, raczej, w końcu, właśnie.

Nie wzięto pod uwage jednostek, które w słownikach przeznaczonych dla uczących się języka polskiego i Innym słowniku języka polskiego kwalifikowane sa jako partykuły, jednak nie należą do tej klasy w SGPP. Sa to: $a$, ale, czy, już, nie, niestety, no, $w$ ogóle (nie), to, aż, przecież, prawie.

Przedmiotem tego artykułu jest 11 partykuł w rozumieniu SGPP, które zostały wielokrotnie użyte w trzech wybranych podręcznikach (wytłuszczone powyżej). Zasób ten skonfrontowano $z$ czterema listami haseł $z$ opracowań dotyczących słownictwa minimum i słownictwa wspólnego, by określić, czy partykuły użyte w podręcznikach należą do podstawowego zasobu leksykalnego języka polskiego i poziomu kompetencji językowej A1 w nauczaniu języka polskiego jako obcego. Po pierwsze, z listami 
zawartymi w publikacji pt. Język polski jako obcy. Programy nauczania na tle badań współczesnej polszczyzny. Zbiór materiałów opracowany przez Komisje Ekspertów Ministerstwa Edukacji Narodowej, pod redakcja W. Miodunki, tj. Lista haseł do słownika-minimum współczesnej polszczyzny (I poziom nauczania), zamieszczona jako aneks w rozdziale Dobór słownictwa do nauczania języka jako obcego [Zgółkowa 1992], oraz listami tzw. modulantów $z$ rozdziału Charakterystyka ilościowa modulantów autorstwa J. Antas [Antas 1992]. Po drugie, $z$ wykazem słownictwa ogólnopolskiego, wspólnoodmianowego, nienacechowanego stylistycznie, zawartego w Leksyce wspólnej różnym odmianom polszczyzny [Markowski 1992]. Po trzecie, z Listami wyrazowymi skompilowanymi na potrzeby badań uczacych sie języka polskiego jako obcego [Seretny 2011], które zostały utworzone na podstawie list H. Zgółkowej [1992], uzupełnionych o słownictwo nowsze [zob. Seretny 2011, 176] i uporządkowanych w grona wyrazowe [zob. Seretny 2011, 183].

Następnie porównano definicje znaczeń partykuł w SGPP, Innym słowniku języka polskiego pod red. M. Bańki i trzech słownikach dla uczacych sie języka polskiego jako obcego $z$ materiałem ilustracyjnym zawartym $\mathrm{w}$ podręcznikach.

\section{LISTY WYRAZOWE}

W niektórych spośród wziętych pod uwage publikacji autorzy definiuja pojęcie klasy partykuł. H. Zgółkowa odnosi się do ich tradycyjnego rozumienia i zalicza partykuły obok wykrzykników do haseł „pragmatycznych”, „ich podstawowa funkcja jest ujawnienie stosunku mówiącego do aktualnie realizowanej wypowiedzi" [Zgółkowa 1992, 41]. Do słownika minimum badaczka zakwalifikowała 51 jednostek, spośród których $40 \mathrm{~S}$. Jodłowski zaliczył do modulantów, spełniajacych funkcję pragmatyczną: sytuujących, waloryzujących, osadzających, życzących, wprowadzajaccych, pytających i afektujących [Zgółkowa 1992, 46]. Pojęciem modulantów posługuje się w tym samym zbiorze studiów J. Antas, która za S. Jodłowskim przyjmuje, że

nie sa [one] składnikami zdania, ale w przeciwieństwie do innych synsemantycznych części mowy (...) mają wolna pozycję składniową, tzn. moga określać lub odnosić się do wolnego składnika zdania; bez względu na to, jaki składnik zdania określają (...), treści, które wnoszą do struktury wypowiedzi sytuują się zawsze poza zdaniem, w tym sensie, że stanowia ramę modyfikacyjna propozycji sądu i dają się opisywać w terminach presupozycji i jej operatorów [Antas 1992, 270].

Dalej autorka pisze, że

są to więc jednostki wprawdzie pełnowartościowe semantycznie, ale ich walor semantyczny jest w pełni funkcyjny: zastępuja niejako całe złożone konstrukcje wy- 
powiedzeniowe, mające za zadanie wprowadzenie określonego typu ustosunkowania odpodmiotowego, wyrażanego presupozycyjnie [Antas 1992, 271].

Klasyfikacja modulantów w tej pracy przedstawia się następująco:

- zacieśnienie referencjalnego charakteru odniesienia (np. sytuanty jak tylko),

- wyznaczenie ustosunkowania waloryzującego (np. owszem, istotnie),

- określenie waloru modalnego (np. chyba, zapewne, być może),

- wyrażenie ustosunkowania afektacyjnego (np. niestety, na szczęście, no, przecież),

- ustanowienie określonej ramy metajęzykowej (np. modulanty wprowadzajace: mianowicie, na przykład) [Antas 1992, 271].

$\mathrm{Na}$ Liście haseł do słownika minimum wspótczesnej polszczyzny (I poziom nauczania) [Zgółkowa 1992; dalej Lista I] znajdują się prawie wszystkie $z$ nich, nie zanotowano jedynie wyrażenia na przykład, którego nie ma również na listach słownictwa na wyższe poziomy, ale sa formy na i przykład.

Wszystkie jednostki znajdują się na listach modulantów [Antas 1992], $z$ czego $8 \mathrm{w}$ wykazie najczęstszych (powyżej $100 \mathrm{w}$ materiale): chyba, jeszcze, może, oczywiście, tylko, również, też, także, dwa - w trzecim przedziale frekwencyjnym (od 10 do 100): na pewno, szczególnie, a jeden - na przykład - w przedziale o najmniejszej frekwencji (poniżej 10).

W zbiorze wyrazów w Leksyce wspólnej różnym odmianom polszczyzny [Markowski 1992] sa tylko cztery jednostki: chyba, może, na pewno, oczywiście, a brakuje siedmiu: jeszcze, na przykład, również, szczególnie, także, té், tylko. Natomiast na liczącej ok. 1200 wyrazów liście Słownictwo minimum - przedziat gron 1-1000, przeznaczonej dla poziomu A1 [Seretny 2011], znalazły się niemal wszystkie wymienione partykuły, poza na przykład.

\section{SLOWNIKI DLA UCZĄCYCH SIĘ JEZYKA POLSKIEGO JAKO OBCEGO}

Wzięte pod uwagę słowniki sa przeznaczone dla uczących się języka polskiego jako obcego lub - jak w wypadku Innego słownika języka polskiego pod red. M. Bańki [Warszawa 2000] - uczyniono ich przynajmniej możliwymi adresatami. Słownik nie notuje wyrazów bardzo rzadkich, przestarzałych i terminów specjalistycznych, a więc również takich partykuł. Klasę tę autorzy rozumieją jako wyrazy nieodmienne, występujące najczęściej przed wyrazem określanym; mogące określać nie tylko czasowniki, przymiotniki i przysłówki (jak przysłówki), lecz także inne części mowy [ISJP, XXXIV]. Ma ona szerszy zakres niż w SGPP i do partykuł zostały zaliczone takie jednostki jak na przykład tuż, które M. Grochowski klasyfikuje jako operator adsubstantywny [Grochowski 1997]. Słownik notuje wszystkie partykuły będące przedmiotem tego artykułu. 
Słownik minimum języka polskiego pod red. H. Zgółkowej [Kraków 2013] jest przeznaczony dla poziomów A1 i A2 i zawiera 2144 hasła. Powstał w ramach tych samych badań, co zbiór materiałów [Miodunka 1992], jednak brak w nim części partykuł wymienionych tam na Liście I, która odpowiada tym poziomom. Słownik podstawowy języka polskiego dla cudzoziemców autorstwa B. Bartnickiej i R. Sinielnikoff [Warszawa 1979] zawiera około 5000 haseł $i$ jest przeznaczony dla uczacych się polskiego na pierwszym etapie. Powstał na podstawie Małego słownika języka polskiego oraz list frekwencyjnych, które były bazą list haseł w zbiorze materiałów [Miodunka 1992]. Również pięciotysięczny Ilustrowany słownik podstawowy języka polskiego wraz $z$ indeksem pojęciowym wyrazów $i$ ich znaczeń pod red. Zofii Kurzowej [Kraków 2005] został opracowany na podstawie słowników języka polskiego oraz wyżej wymienionych słowników dla uczacych się. Słowniki te nie definiuja terminu partykuła.

We wszystkich trzech słownikach można odnaleźć 7 jednostek partykułowych będących przedmiotem analizy (jeszcze, może, oczywiście, również, także, też, tylko), w dwóch (SPJPdC, ISPJP) jest obecna jeszcze jedna (chyba), a tylko w jednym (ISPJP) zanotowano kolejna (szczególnie). Hasło o postaci chyba jest zakwalifikowane w SMJP jako spójnik, jednostka o postaci na pewno została zanotowana jako przysłówek w SPJPdC, szczególnie nie ma kwalifikacji w SMJP, natomiast na przy$k ł a d$ - w żadnym słowniku.

Poniżej znajduja się zestawienia definicji słownikowych i ilustracji materiałowej dla czterech $z$ omawianych partykuł (chyba, może, na pewno, oczywiście), które w SGPP zostały zakwalifikowane do partykuł epistemicznych i zostały uwzględnione w opracowaniu pt. Leksyka wspólna różnym odmianom polszczyzny [Markowski 1992], na Liście I [Zgółkowa 1992], liście modulantów [Antas 1922] oraz liście gron wyrazowych dla poziomu A1 [Seretny 2011]. Z pewnością sa to więc jednostki, których i o których należy uczyć na początkowym etapie. Jednocześnie jednej $z$ nich $w$ ogóle nie znajdziemy w słownikach przeznaczonych dla uczących się języka polskiego jako obcego.

\section{PARTYKUEY EPISTEMICZNE}

\section{A. Niewykluczające}

\section{Chyba}

Reprezentacja semantyczna w SGPP jest następująca: 'mówiący o tym, o czym mowa [wiesz, o czym], o czym nie jest tak, że wie, że nie R, mówi, że jest możliwe, że nie R'.

Według definicji w ISJP słowa tego używamy, „zwykle w zdaniach oznajmujacych, kiedy nie wiemy, czy to, o czym mówimy, jest prawdą, 
i chcemy wyrazić przypuszczenie, że jest”, według ISPJP „wskazuje, że mówiący nie wie czegoś dokładnie, ale decyduje się powiedzieć, sądząc, $\dot{z}$ e to prawda". Znacznie mniej precyzyjna jest definicja w SPJPdC, zgodnie $z$ która chyba to "partykuła osłabiająca, oznaczająca niepewność”. ${ }^{1}$

Jako modulant chyba zostało zakwalifikowane do modulantów o funkcji modalnej, a przez A. Markowskiego do dwóch grup tematycznych: <Wola i oceny $z$ nią związane - 'sądy'> oraz < Rozum, pamięć, wyobraźnia i oceny $z$ nimi zwiazane - 'wskaźniki pewności sądu'>.

Ilustracja tych definicji moga być następujące użycia w zdaniach oznajmujaccych, w antepozycji względem rematu:

Nie pamiętam dobrze, ale chyba Maria [Krok, 32]. ${ }^{2}$

Chyba jeszcze kilka kartonów soku i wodę mineralna [Krok, 101].

Słuchaj, chyba nie ma sensu jechać dzisiaj na tę wycieczkę. Jest pochmurno i zaraz będzie deszcz [Hurra 1, 122].

Jedyne wystapienie w podręczniku Polski jest cool poświadcza użycie tej partykuły w pytaniu o upewnienie:

Ale chyba nie będziesz spotykać się z nim codziennie? [Cool, 296].

Pojawiło się również jedno poświadczenie zgodne $z$ informacja pragmatyczna z SGPP, że chyba „może być użyte do skorygowania wypowiedzi innej osoby":

Ale to chyba nie jego koleżanka, tylko dziewczyna [Krok, 73].

\section{Może}

Reprezentacja semantyczna w SGPP: 'mówiący o tym, o czym mowa, o czym nie jest tak, że wie, że nie R, nie mówi, że R i nie mówi, że nie R'.

W ISJP znajdujemy cztery jednostki. Tej opatrzonej numerem 1 „używamy w zdaniach oznajmujących, aby powiedzieć, że nie wykluczamy prawdziwości tego, o czym mowa. Według ISPJP może „1. wprowadza przypuszczenie, że to, o czym się mówi, jest prawdziwe lub możliwe”, według SMJP „nadaje wypowiedzi charakter przypuszczenia, osłabienia lub tworzy atmosferę grzeczności”.

J. Antas [1992] określa może jako modulant o funkcji modalnej, a A. Markowski kwalifikuje je do grupy tematycznej: <Rozum, pamięć, wyobraźnia i oceny z nimi związane - 'wskaźniki pewności sądu'>.

1 W haśle chyba pod numerem 2. SPJPdC notuje eksplikację: "partykuła wzmacniająca zdanie ze znaczeniem warunku, wyjątku»: Na pewno przyjdę, chyba żebym zachorował. W ISJP natomiast jednostka chyba że jest zakwalifikowana jako spójnik centralny aglutynacyjny [zd $+z d$ : przesz]

2 Cytowane zdania sa opatrzone informacjami o lokalizacji: skrótem tytułu podręcznika i numerem strony po przecinku. 
Przykłady z podręczników są następujące:

Nie mam konkretnych planów na weekend, może będę czytać książkę [Hurra 1, 94]. Niestety, nie jestem specjalistka, ale może twoja nauczycielka wie [Krok, 45].

- To zależy od pogody. Może być ładnie, ale też może być brzydko. Jesteśmy w Polsce, he, he [Krok, 107].

SPJPdC notuje natomiast użycie tej partykuły jako odpowiedzi: „1 nadająca odpowiedzi odcień możliwości”, czego poświadczeniem może być zdanie:

Może być herbata, ale bez cytryny [Krok, 113].

Redaktorzy SGPP zanotowali również informację pragmatyczną: „W zdaniach $z$ czasownikiem $\mathrm{w}$ czasie przyszłym $z$ intonacja pytajna wyraża propozycję lub zachętę". W ISJP tę informację zawiera jednostka 2., w ISPJP i SPJPdC znaczenia 2. W jednym $z$ podręczników znajduje się zdanie ilustrujące takie użycie:

Może pójdziemy do kawiarni albo na koncert? [Hurra 1, 73].

Jednak propozycję lub zachętę może wyrażać również zdanie $z$ czasownikiem w czasie teraźniejszym:

- Mami, wolisz jasny czy ciemny chleb?

(...)

- A co to jest?

- To jest bułka. Może wolisz bułkę.

- Tak, proszę bułkę [Krok, 53].

W podręczniku Krok po kroku znalazło się także jedno zdanie potwierdzające użycie tej partykuły w pytaniu rozstrzygnięcia:

[Klient:] - Kilogram pieczarek. [Sprzedawca] - Może być dziesięć deka więcej? [Krok, 99].

Inne, nieuwzględnione w słownikach użycie występuje w podręczniku Polski jest cool. W zdaniu tym została wyrażona grzeczna odmowa:

- Przepraszam, ale dzisiaj nie mogę. Może innym razem? [Cool, 185].

\section{B. Przeświadczenia}

\section{Oczywiście}

W SGPP partykuła ta ma następująca reprezentację: 'nadawca, mówiąc o tym, o czym mowa, mówi, że wiedząc to, co on o tym wie pod danym względem, nie można powiedzieć, że nie R'. 
Według ISJP słowa tego „używamy, aby powiedzieć, że coś jest całkowicie oczywiste i nie powinno budzić wątpliwości", ${ }^{3}$ a SMJP notuje, że oczywiście „potwierdza przekonanie mówiącego o tym, czego dotyczy wypowiedž".

ISPJP wymienia dwa znaczenia: 1. 'wyraża przekonanie mówiącego, że inny stan rzeczy nie jest możliwy' i 2. 'daje twierdzacą odpowiedź na pytanie', podobnie czyni SPJPdC: 1 "partykuła twierdzaca: tak, naturalnie, $z$ cała pewnościa, na pewno" oraz 2 "partykuła wyrażająca stosunek mówiącego do treści zdania: głębokie przekonanie, że tak jest naprawdę". Te dwa znaczenia w poprzednich trzech leksykonach sa jednym.

Według J. Antas [1992] oczywiście jest modulantem o funkcji waloryzującej (potwierdzeniem) i mieści się w zasobie podstawowym polszczyzny. A. Markowski kwalifikuje je do grupy tematycznej: <Uczucia, emocje, oceny uczuciowe i emocjonalne - 'oceny'>.

Przykładowe wystapienia w podręcznikach:

No i oczywiście uwielbiam mocna czarna kawę! [Cool, 192].

Marta jest oczywiście znów niepunktualna [Hurra, 64].

Sa w nim oczywiście jajka, chleb, kawałek mięsa i kiełbasy, sól (...) [Hurra, 147].

Oczywiście, mam chłopaka [Krok, 71].

W podręcznikach nie pojawia się samodzielne użycie partykuły oczywiście, które wymieniają słowniki.

\section{Pewnościowa}

\section{Na pewno}

Partykuła ta nie znalazła się w żadnym słowniku przeznaczonym dla cudzoziemców uczących się języka polskiego jako obcego. W SPJPdC zanotowano wyrażenie o takiej postaci jako przysłówek o znaczeniu $<z$ pewnościa, bez wątpienia $>$, natomiast redaktorzy SGPP nie potwierdzają istnienia jednostek homonimicznych należących do innych klas.

Występuje ono w ISJP, w którym ujęto je w haśle pewno. Redaktorzy ISJP definiuja je następująco: „1 Wyrażenia na pewno używamy, aby powiedzieć, że jesteśmy o czymś całkowicie przekonani”. ${ }^{4}$

3 Definicja odsyła więc do jednostki oczywisty w znaczeniu 1., która została wytłumaczona następująco: „Coś, co jest oczywiste, nie budzi żadnych wątpliwości”. Jak widać, definicje są takie same i odsyłają do jednostki wątpliwość (1. „Jeśli mamy wątpliwości co do czegoś, to nie jesteśmy pewni, czy jest to prawdziwe, możliwe lub odpowiednie. Jeśli nie mamy wątpliwości co do czegoś, to jesteśmy tego całkowicie pewni”).

4 Definicja ta odsyła do hasła przekonać, czasownik ten ma następująca definicję: „Jeśli jakaś osoba, jej wypowiedź, jakaś sytuacja itp. przekonała nas o czymś lub jeśli przekonaliśmy się o czymś, to na podstawie otrzymanych in- 
W SGPP reprezentacja semantyczna na pewno jest następujaca: 'nadawca, mówiąc o tym, o czym mowa, że R, mówi, że wie coś, co jest prawdziwe, gdy jest R, i że nie wie niczego takiego, co wiedząc, nie można by powiedzieć, że R'.

J. Antas [1992] kwalifikuje na pewno jako modulant o funkcji modalnej osadzajacej, wyrażenie to nie znajduje się tam w zasobie podstawowym, lecz wśród słownictwa rzadszego (III przedział frekwencyjny o częstości występowania $\mathrm{F}(\mathrm{t})<100<10$ ). W Leksyce wspólnej A. Markowskiego [1992] wyrażenie na pewno przypisano do grupy tematycznej $<$ Rozum, pamięć, wyobraźnia i oceny z nimi związane - 'wskaźniki pewności sądu'>.

W podręcznikach znajdziemy przykładowe ilustracje, w wypowiedzeniach oznajmujacych i odpowiedziach na pytanie:

\footnotetext{
Ekscytująca książka! Jutro na pewno ją skończę [Krok, 145].

To na pewno Rafał [Cool, 164].

(Czy moge tutaj kupić bilet?) Niestety u nas nie, ale na pewno na lotnisku [Hurra, 110].

Tak, tak, na pewno [Krok, 48].
}

Pozostałe siedem wybranych partykuł należy według Słownika gniazdowego partykuł polskich do partykuł porównywania. Partykułami analogii są: jeszcze, również, także i też, partykułami wyróżniającymi są: szczególnie i tylko, a partykuła egzemplifikacji - na przykład.

Przegląd informacji - zawartych w podręcznikach do nauczania języka polskiego jako obcego, słownikach, listach wyrazów tworzonych na potrzeby glottodydaktyki oraz w zestawieniu leksyki wspólnej dotyczacych jedenastu wybranych partykuł - ukazuje:

- różnice dotyczące przynależności do słownictwa podstawowego (listy na potrzeby glottodydaktyki) i wspólnoodmianowego, neutralnego [Markowski 1992],

- odmienne klasyfikacje tych jednostek w różnych opracowaniach leksykologicznych,

- niewystarczajace dla uczacych się sposoby definiowania, zbyt trudne lub zbyt ogólne definicje,

- czasami pojedyncze, a więc przypadkowe i być może zbędne użycia omawianych jednostek $\mathrm{w}$ tekstach podręcznikowych,

- brak systematycznych ćwiczeń w materiałach dydaktycznych oraz adekwatnych źródeł wiedzy o znaczeniach i używaniu partykuł.

Artykuł przedstawia mały wycinek podjętych prac, które maja na celu opracowanie kompleksowego, praktycznego kompendium użycia partykuł (i ewentualnie innych wyrażeń metatekstowych) na potrzeby naucza-

formacji, swojej wiedzy lub doświadczenia nabraliśmy pewności, że jest to prawdziwe lub słuszne". 
nia języka polskiego jako obcego. Byłoby ono niezwykle przydatne dla lektorów, twórców materiałów dydaktycznych i uczących się.

Rozpoczęte prace wymagaja ekscerpcji jednostek partykułowych $z$ podręczników kursowych, podręczników do nauczania czytania i lektur przeznaczonych dla uczących się języka polskiego, by zebrać leksemy rzeczywiście zamieszczone w tekstach czytanych przez uczacych się. Następnie - na podstawie badań wykonanych przez twórców SGPP - należy przeprowadzić ich analizę składniowa i semantyczną w obrębie tekstów dydaktycznych, w których występuja. Analiza ta pozwoli na skatalogowanie znaczeń, użyć i funkcji tekstowych zebranych jednostek na poziomie odpowiednim dla uczących się, którzy mają trudności z rozpoznaniem różnic między wyrazami również, też, także, chca poznać zasady użycia chyba i może, dowiedzieć się, w jakim typie zdań posłużyć się wyrazem jednak. Zestawienie tego materiału ze słownikami dla cudzoziemców oraz najnowszymi opracowaniami leksykograficznymi obejmującymi polszczyznę ogólna, które wykorzystują metodologię właściwą angielskojęzycznym słownikom pedagogicznym i osiągnięcia współczesnego językoznawstwa w zakresie opisu jednostek leksykalnych, umożliwi opracowanie dostępnego dla niewyrobionych użytkowników polszczyzny kompendium, $z$ którego zaczerpną ujednoliconą i odpowiednio szczegółowa wiedzę o znaczeniach i stosowaniu niełatwych wyrazów, jakimi sa partykuły. Opracowane informacje semantyczne, składniowe i pragmatyczne dotyczące użycia partykuł w tekstach skierowanych do uczacych się polszczyzny pozwoli także przygotować ćwiczenia wprowadzające i utrwalające umiejętność posługiwania się tą klasą leksemów.

\section{Bibliografia}

\section{$\underline{\text { Podrẹczniki }}$}

I. Stempek i in., 2010, Polski krok po kroku. Seria podręczników do nauki języka polskiego dla obcokrajowców. Poziom A1, Kraków.

E. Piotrowska-Rola, M. Porębska, 2013, Polski jest cool. Seria do nauki języka polskiego jako obcego na poziomie A1. Ksiażka studenta, Lublin.

M. Małolepsza, A. Szymkiewicz, 2006, Hurra!!! Po polsku 1. Podręcznik studenta, wyd. II, Kraków.

\section{Slowniki}

B. Bartnicka, R. Sinielnikoff, 1979, Słownik podstawowy języka polskiego dla cudzoziemców, Warszawa.

M. Grochowski, A. Kisiel, M. Żabowska, 2014, Słownik gniazdowy partykuł polskich, Kraków [SGPP].

M. Grochowski, 1997, Wyrażenia funkcyjne. Studium leksykograficzne, Kraków.

Z. Kurzowa, 2005, Ilustrowany słownik podstawowy jezyka polskiego wraz $z$ indeksem pojęciowym wyrazów $i$ ich znaczeń, Kraków. 
H. Zgółkowa, 2013, Słownik minimum języka polskiego, Kraków.

M. Bańko, 2000, Inny słownik języka polskiego, Warszawa.

\section{Literatura}

J. Antas, 1992, Charakterystyka ilościowa modulantów [w:] W. Miodunka (red.), Język polski jako obcy. Programy nauczania na tle badań wspótczesnej polszczyzny. Zbiór materiałów opracowany przez Komisję Ekspertów Ministerstwa Edukacji Narodowej, Kraków, s. 269-306.

A. Markowski, 1992, Leksyka wspólna różnym odmianom polszczyzny, Wrocław. W. Miodunka (red.), 1992, Język polski jako obcy. Programy nauczania na tle badań współczesnej polszczyzny. Zbiór materiałów opracowany przez Komisje Ekspertów Ministerstwa Edukacji Narodowej, Kraków.

A. Seretny, 2011, Kompetencja leksykalna uczacych się języka polskiego jako obcego $w$ świetle badań ilościowych, Kraków.

H. Zgółkowa, 1992, Dobór słownictwa do nauczania języka polskiego jako obcego [w:] W. Miodunka (red.), Język polski jako obcy. Programy nauczania na tle badań współczesnej polszczyzny. Zbiór materiałów opracowany przez Komisję Ekspertów Ministerstwa Edukacji Narodowej, Kraków, s. 39-64.

H. Zgółkowa, 1992, Lista haseł do słownika minimum współczesnej polszczyzny (I poziom nauczania) [w:] Język polski jako obcy. Programy nauczania na tle badań współczesnej polszczyzny. Zbiór materiałów opracowany przez Komisję Ekspertów Ministerstwa Edukacji Narodowej, Kraków, s. 67-77 [Lista I].

\section{Particles in teaching Polish as a foreign language at the level A1. On the material of textbooks and dictionaries for learners of Polish as a foreign language}

Summary

This paper presents an overview of the words belonging to the class of particles (as defined by SGPP (Nest Dictionary of Polish Particles)) used in textbooks for teaching Polish as a foreign language at initial stages and compares their set to the contents of the lexis lists prepared with glottodidactics and dictionaries for foreigners in mind. The usages of units such as chyba (probably), może (maybe), oczywiście (certainly), and na pewno (surely) in the textbook material were then confronted with their meanings and usages specified in lexicographic studies in order to identify the adequacy of the lexicographic description. Attention was drawn to the non-uniform classification of the units into lexeme classes, definition methods that are improper for unskilled users of Polish, lack of regularity in using particles in textbook texts and exercises teaching their usages. A compendium with the semantic, syntactic, and pragmatic descriptions of the particles for the purposes of Polish glottodidactics was proposed.

Keywords: particles - meaning - usage - teaching Polish as a foreign language - textbooks for teaching Polish as a foreign language. 